\title{
Survival, growth and metabolic parameters of silver catfish, Rhamdia quelen, juveniles exposed to different waterborne nitrite levels
}

\author{
Ronaldo L. de Lima ${ }^{1}$, Neiva Braun ${ }^{1}$, Daiani Kochhann², Rafael Lazzari ${ }^{3}$, João Radünz \\ Neto $^{4}$, Bibiana S. Moraes ${ }^{5}$, Vania L. Loro ${ }^{5}$ and Bernardo Baldisserotto ${ }^{6}$
}

High nitrite $\left(\mathrm{NO}_{2}^{-}\right)$levels may develop in aquaculture systems due to high fish density, but studies of lethal concentration values and the effect of $\mathrm{NO}_{2}^{-}$on metabolic parameters and growth are scarce. Consequently, in this study was verified the lethal

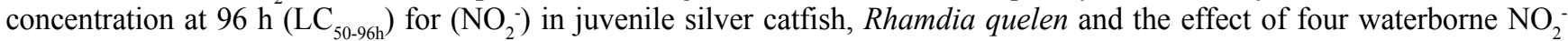
concentrations $\left(0.06,0.46,1.19\right.$, and $\left.1.52 \mathrm{mg}^{-\mathrm{L}^{-1}}\right)$ on growth, and hepatic and muscular lactate, glucose, glycogen and protein. Nitrite $\mathrm{LC}_{50-96 \mathrm{~h}}$ was 20.46 (confidence interval: $\left.16.10-23.68\right) \mathrm{mg} . \mathrm{L}^{-1}$. In the growth experiment, exposure to $\mathrm{NO}_{2}$-did not affect weight, length or specific growth rate, but due to mortality ( $66.7 \%$ and $100 \%$ after 20 and 40 days, respectively), biomass of juveniles exposed to $1.52 \mathrm{mg} . \mathrm{L}^{-1} \mathrm{NO}_{2}{ }^{-}$was significantly lower than the biomass of juveniles exposed to other treatments. Therefore, the safe level of nitrite for growth of silver catfish juveniles is below $1.19 \mathrm{mg} \cdot \mathrm{L}^{-1}\left(2 \% \mathrm{of} \mathrm{LC}_{50-96 \mathrm{~h}}\right)$. Exposure of silver catfish to $\mathrm{NO}_{2}^{-}$for 40 days reduced lactate levels in muscle, but lactate levels increased in liver tissue of fish maintained at $1.19 \mathrm{mg} \cdot \mathrm{L}^{-1} \mathrm{NO}_{2}^{-}$. In addition, glucose levels in muscle and liver tissues were significantly lower in silver catfish exposed to the highest $\mathrm{NO}_{2}{ }^{-}$level. These results indicate that chronic $\mathrm{NO}_{2}^{-}$exposure causes anaerobic substrate oxidation to meet energy demand.

Altos níveis de nitrito $\left(\mathrm{NO}_{2}^{-}\right)$podem ocorrer em sistemas de cultivo com alta densidade de estocagem, mas análises sobre os valores de concentração letal e o efeito do $\mathrm{NO}_{2}^{-}$em parâmetros metabólicos e no crescimento são escassos. Neste estudo foi analisada a concentração letal em $96 \mathrm{~h}\left(\mathrm{CL}_{50-96 \mathrm{~h}}\right)$ para nitrito $\left(\mathrm{NO}_{2}^{-}\right)$em juvenis de jundiá, Rhamdia quelen, e o efeito de quatro níveis de nitrito $\left(0,06 ; 0,46 ; 1,19 \mathrm{e} 1,52 \mathrm{mg} \cdot \mathrm{L}^{-1}\right)$ no crescimento e no lactato, glicose, glicogênio e proteína hepática e muscular. $\mathrm{A} \mathrm{CL}_{50-96 \mathrm{~h}}$ para $\mathrm{NO}_{2}{ }^{-}$foi 20,46 (intervalo de confiança: $\left.16,10-23,68\right) \mathrm{mg}$. $\mathrm{L}^{-1}$. No experimento de crescimento, a exposição ao $\mathrm{NO}_{2}^{-}$ não afetou o peso, comprimento ou taxa de crescimento específico, mas devido à mortalidade $(66,7 \%$ e $100 \%$ após 20 e 40 dias, respectivamente), a biomassa dos juvenis expostos a 1,52 mg. $\mathrm{L}^{-1}$. $\mathrm{NO}_{2}{ }^{-}$foi significativamente mais baixa que a biomassa dos juvenis expostos aos outros tratamentos. Deste modo, o nível seguro de $\mathrm{NO}_{2}^{-}$para o crescimento do jundiá é abaixo de 1,19 $\mathrm{mg} . \mathrm{L}^{-1}\left(2 \%\right.$ da $\left.\mathrm{CL}_{50-96 \mathrm{~h}}\right)$. A exposição do jundiá ao $\mathrm{NO}_{2}^{-}$por 40 dias diminuiu os níveis de lactato no músculo, mas esses níveis aumentaram nos exemplares mantidos em $1,19 \mathrm{mg} \cdot \mathrm{L}^{-1} \mathrm{NO}_{2}^{-}$. Além disso, os níveis de glicose no músculo e fígado foram significativamente mais baixos nos jundiás expostos à concentração mais elevada de $\mathrm{NO}_{2}^{-}$. Estes resultados indicam que a exposição crônica ao $\mathrm{NO}_{2}^{-}$provoca uma oxidação anaeróbica do substrato para obtenção de energia.

Key words: Nitrogenous compound, Jundiá, Glucose, Lactate.

\section{Introduction}

Nitrite $\left(\mathrm{NO}_{2}^{-}\right)$is found in ecosystems as a natural component of the nitrogen cycle (Jensen, 2003). Ammonia is the main nitrogenous waste material produced from amino acid catabolism; in water, ammonia is reduced to $\mathrm{NO}_{2}^{-}$by nitrifying bacteria before its conversion into nitrate (Costa et al., 2004). The concentration of $\mathrm{NO}_{2}^{-}$is usually low $\left(0.03-0.1 \mathrm{mg} . \mathrm{L}^{-1}\right)$ in tropical fish culture systems with low stocking density (Sipaúba-Tavares et al., 1999; Andrade et al., 2007), but an imbalance in either ammonia production or $\mathrm{NO}_{2}^{-}$conversion to nitrate can cause $\mathrm{NO}_{2}^{-}$buildup (Jensen, 2003). High $\mathrm{NO}_{2}^{-}$levels may develop in aquaculture systems due to high fish density (Hargreaves, 1998) or due to fertilizers added to the water (Lewis \& Morris, 1986). In these systems, $\mathrm{NO}_{2}^{-}$levels can reach 45 mg. $\mathrm{L}^{-1}$ or more upon establishment of nitrification in biological

\footnotetext{
${ }^{1}$ Departamento de Aquicultura, Universidade Federal de Santa Catarina, Florianópolis, SC, Brazil.

${ }^{2}$ Laboratório de Ecofísiologia e Evolução Molecular, Instituto Nacional de Pesquisas da Amazônia, Manaus, AM, Brazil.

${ }^{3}$ Departamento de Zootecnia, Centro de Educação Superior Norte do Rio Grande do Sul, Palmeira das Missões, RS, Brazil.

${ }^{4}$ Departamento de Zootecnia, Universidade Federal de Santa Maria, Santa Maria, RS, Brazil.

${ }^{5}$ Departamento de Química, Universidade Federal de Santa Maria, Santa Maria, RS, Brazil.

${ }^{6}$ Departamento de Fisiologia e Farmacologia, Universidade Federal de Santa Maria, Santa Maria, RS, Brazil. bernardo@smail.ufsm.br
} 
filters or during imbalance in the process (Collins et al., 1975; Avnimelech et al., 1986; Kamstra et al., 1996).

An increase of waterborne $\mathrm{NO}_{2}^{-}$levels induces $\mathrm{NO}_{2}$ accumulation in fish blood and tissues from 10 to 100 times the environmental concentration (Holt \& Arnold, 1996; Costa et al., 2004) which produces toxic derivatives with deleterious effects on physiological processes (Jensen et al., 1987). Despite the importance of such effects, the lethal concentration at $96 \mathrm{~h}\left(\mathrm{LC}_{50-96 \mathrm{~h}}\right)$ for $\mathrm{NO}_{2}^{-}$was determined only in a few neotropical freshwater fish species (Avilez et al., 2004; Costa et al., 2004), and the effect of a single level of this nitrogenous compound for $8 \mathrm{~h}$ on biochemical parameters was analyzed in traira, Hoplias malabaricus (Moraes et al., 1998), pacu, Piaractus mesopotamicus and the hybrid tambacu (Piaractus mesopotamicus x Colossoma macropomum) (Moraes et al., 2006).

Nitrite reduces growth in silver perch, Bidyanus bidyanus (Frances et al., 1998) and rainbow trout, Onchorhynchus mykiss (Kroupova et al., 2008). Exposure to $\mathrm{NO}_{2}^{-}$increases methemoglobin, a form of hemoglobin incapable of binding oxygen, in channel catfish (Urrutia \& Tomasso, 1987), but not in rainbow trout (Kroupova et al., 2008). Long term exposure to $\mathrm{NO}_{2}{ }^{-}$provokes lamellar hyperplasia and increases plasma glucose levels in rainbow trout (Kroupova et al., 2008), but does not induce any histopathological changes in the gills of silver perch (Frances et al., 1998). Because of those variable effects on different fish species, the objective of this study was to verify the $\mathrm{LC}_{50-96 \mathrm{~h}}$ for $\mathrm{NO}_{2}^{-}$in silver catfish, Rhamdia quelen. As knowledge of the effect of $\mathrm{NO}_{2}^{-}$on growth is scarce, and its chronic effect on metabolic parameters (glucose, glycogen, lactate) is unknown, in the present study it was also tested the effect of $\mathrm{NO}_{2}{ }^{-}$on these parameters in silver catfish. This species was used because it is one of the main native species raised in southern Brazil (Baldisserotto, 2009). As exposure to high $\mathrm{NO}_{2}^{-}$levels compromises oxygen transport (Spotte, 1979; Aggergaard \& Jensen, 2001), the study of the selected biochemical parameters in liver and muscle is important to analyze the metabolic behavior of the fish against internal hypoxia and its consequences to growth.

\section{Material and Methods}

Experimental animals and management conditions. Silver catfish juveniles were obtained from fish farmers near Santa Maria, southern Brazil, and transported to the Fish Physiology Laboratory at the Universidade Federal de Santa Maria (voucher specimen catalogued as UFRGS 14114 in the fish collection at Departamento de Zoologia, Universidade Federal do Rio Grande do Sul, Brazil). Fish were maintained in continuously aerated 250-L tanks for a period of 3 weeks prior to each experiment for acclimation. The experimental diet was composed mainly of yeast and soybean meal and $320 \mathrm{~g} . \mathrm{kg}^{-1}$ crude protein, $0.17 \mathrm{~g}$ NaCl. $\mathrm{kg}^{-1}$ food and was prepared according to Garcia et al. (2007). Fish were fed once per day (5\% of body mass). Uneaten food, as well as other residue and feces, were siphoned $30 \mathrm{~min}$ after feeding. The measured $\mathrm{Na}^{+}, \mathrm{K}^{+}$, and $\mathrm{Cl}^{-}$concentrations of the food were (mean $\pm \mathrm{SEM}$ ): $3 \pm 0.1,56 \pm 4.4$, and $10.8 \pm 3.5$ mmol. $\mathrm{kg}^{-1}$, respectively. Waterborne $\mathrm{Na}^{+}, \mathrm{K}^{+}$, and $\mathrm{Cl}^{-}$were 21.85 , 1.95 and $11.3 \mathrm{mg} . \mathrm{L}^{-1}$, respectively.

Determination of $\mathrm{NO}_{2}^{-}$lethal concentration $\left(\mathrm{LC}_{50-96 \mathrm{~h}}\right)$. After the acclimation period silver catfish $(7.16 \pm 0.27 \mathrm{~g})$ were transferred to $2 \mathrm{~L}$ aquaria (10 fish each, 3 replicates) and were exposed for $96 \mathrm{~h}$ to the following waterborne $\mathrm{NO}_{2}^{-}$levels (in $\left.\mathrm{mg} . \mathrm{L}^{-1}\right): 0.08 \pm 0.07,5.33 \pm 0.07,10.66 \pm 0.05,21.33 \pm 0.09$, and $42.66 \pm 0.04$. These levels were maintained through the addition of sodium nitrite $\left(\mathrm{NaNO}_{2}\right.$, Merk, $99.5 \%$ purity) and were chosen based on previous $\mathrm{LC}_{50-96 \mathrm{~h}}$ experiments with neotropical species (Bianchini et al., 1996; Avilez et al., 2004; Costa et al., 2004). All feces and residues were removed daily by suction, and consequently approximately $40 \%$ of the water in the boxes was replaced by water with previously adjusted nitrite levels. Fish were observed every $12 \mathrm{~h}$ and removed when immobile and respiratory movements ceased. Mortality was determined after $96 \mathrm{~h}$ exposure. $\mathrm{LC}_{50-96 \mathrm{~h}}$ was calculated by the probits method (Finney, 1971). As some fish change swimming behavior in response to hypoxia (Braun et al., 2006), swimming behavior of the juveniles was qualitatively observed through the experimental period.

Growth of silver catfish exposed to $\mathrm{NO}_{2}$ - After acclimation, juveniles $(3.01 \pm 0.19 \mathrm{~g}$ and $58.9 \pm 1.3 \mathrm{~mm})$ were placed in continuously aerated 40 -L polypropylene tanks and kept for 40 days (10 juveniles in each tank). The fish were exposed to 4 different levels of waterborne $\mathrm{NO}_{2}^{-}$(in mg. $\mathrm{L}^{-1}$ ): 0.06 (control), $0.46,1.19$, and $1.52\left(0,2.2,5.8\right.$ and $7.4 \%$ of the $\mathrm{LC}_{50-96 \mathrm{~h}}$, respectively - values can be seen in the results) in triplicate. These values were chosen because minimum values of nitrogenous compounds that affect fish growth are in the $3-12 \%$ of $\mathrm{LC}_{50-96 \mathrm{~h}}$ range (Tomasso, 1994). Fish were fed with the same diet of the acclimation, and approximately $20 \%$ of the water in the tanks was replaced by water with previously adjusted nitrite levels. Swimming (position in the water column) and alimentary (fed or not) behaviors of the juveniles were observed throughout the experimental period. Ten fish were collected at 0,20 and 40 days for biometry. Specific growth rate (SGR) was calculated by the equation: $\mathrm{SGR}=(\ln$ initial medium weight $-\ln$ final medium weight) $\times 100 /$ time in days. Biomass $=$ medium weight $\times$ number of final survivors in each analyzed period.

Measurement of biochemical parameters. At the end of the exposure period (40 days), all fish were sampled, stunned with a blow to the head and then euthanized by severing the spinal cord. Procedure was run without anesthesia. Liver and muscle tissue were removed, frozen in liquid nitrogen, and then stored at $-20^{\circ} \mathrm{C}$. Liver and muscle glycogen were determined according to Bidinoto et al. (1997) and tissue protein levels were determined according to Lowry et al. (1951). Tissue samples were homogenized with $10 \%$ trichloroacetic acid using a motordriven Teflon pestle and centrifuged at $1000 \mathrm{xg}$ for $10 \mathrm{~min}$. Deproteinated supernatant was used for the determination of lactate (Harrower \& Brown, 1972) and glucose (Park \& Johnson, 1949) levels. 
Water quality. Water $\mathrm{pH}$ was monitored daily with a DMPH$2 \mathrm{pH}$ meter (Digimed, São Paulo, Brazil). Total ammonia levels were verified once a week by nesslerization according to Greenberg et al. (1976) and non-ionized ammonia levels were calculated according to Piper et al. (1982). Dissolved oxygen and temperature were measured daily with a YSI oxygen meter (model Y5512 YSI Inc. Yellow Springs, USA) and laboratory temperature was maintained by an air conditioner. Levels of total alkalinity and nitrite were determined twice per day according to Boyd (1998). Water hardness was determined by the EDTA titrimetric method (Greenberg et al., 1976). Waterborne and dietary $\mathrm{Na}^{+}$and $\mathrm{K}^{+}$concentrations were measured with a Micronal B286 flame photometer (São Paulo, Brazil), and $\mathrm{Cl}^{-}$concentrations were measured according to Zall et al. (1956).

Statistical analysis. Data were reported as mean \pm SEM. The relationships between $\mathrm{NO}_{2}^{-}$levels with growth parameters (regression-based curve-fitting) were calculated using Sigma Plot 8.0. Homogeneity of variances among groups was tested with the Levene test. Data presented homogeneous variances, and comparisons among different treatments were made by one-way analysis of variance and Tukey test. Analysis was performed using Statistica software (version 5.1) and the minimum significance level was set at $p<0.05$.

The methodology of this experiment was approved by the Ethical and Animal Welfare Committee of the Universidade Federal de Santa Maria (Proc. 24/2007).

\section{Results}

During the experimental period the overall water conditions were: $\mathrm{pH} 7.9 \pm 0.02$, temperature $25.0 \pm 0.1^{\circ} \mathrm{C}$, dissolved oxygen $4.91 \pm 0.04 \mathrm{mg} . \mathrm{L}^{-1}$, total ammonia $1.36 \pm$ $0.03 \mathrm{mg} . \mathrm{L}^{-1}$, non-ionized ammonia $0.06 \pm 0.01 \mathrm{mg} . \mathrm{L}^{-1}$, total alkalinity $41.3 \pm 0.3 \mathrm{mg} \mathrm{CaCO}_{3} \mathrm{~L}^{-1}$, water hardness $39.5 \pm 1.5$ $\mathrm{mg} \mathrm{CaCO} \mathrm{L}^{-1}, \mathrm{Ca}^{2+} 5.2 \mathrm{mg} . \mathrm{L}^{-1}, \mathrm{Na}^{+} 5.54 \pm 0.04 \mathrm{mg} . \mathrm{L}^{-1}, \mathrm{~K}^{+} 1.33$ $\pm 0.06 \mathrm{mg} . \mathrm{L}^{-1}$ and $\mathrm{Cl}^{-} 3.94 \pm 0.02 \mathrm{mg} . \mathrm{L}^{-1}$. Silver catfish exposed up to $5.33 \mathrm{mg} . \mathrm{L}^{-1} \mathrm{NO}_{2}^{-}$presented $100 \%$ survival, and those kept at 10.66, 21.33 and $42.66 \mathrm{mg} . \mathrm{L}^{-1} \mathrm{NO}_{2}{ }^{-}$showed (mean \pm SEM) $80 \pm 11,50 \pm 6$ and $10 \pm 10 \%$ survival, respectively after $96 \mathrm{~h}$. Nitrite $\mathrm{LC}_{50-96 \mathrm{~h}}$ was $20.46 \pm 2.76$ (confidence interval: 16.10-23.68) mg.L.-1 $\mathrm{NO}_{2}^{-}$.

Fish exposed to $1.52 \mathrm{mg} \cdot \mathrm{L}^{-1} \mathrm{NO}_{2}^{-}$presented $66.7 \%$ and $100 \%$ mortality after 20 and 40 days, respectively. In the other treatments no mortality was observed. In the beginning of the growth experiment, juveniles from all treatments sought food as soon as it was offered, but, after 20 days, the juveniles exposed to $1.52 \mathrm{mg} . \mathrm{L}^{-1} \mathrm{NO}_{2}$ - sometimes ignored food. Silver catfish juveniles exposed to all nitrite levels swam near the surface of the water. Exposure to $\mathrm{NO}_{2}{ }^{-}$did not affect weight, length or specific growth rate, but due to mortality, biomass of juveniles exposed to $1.52 \mathrm{mg} . \mathrm{L}^{-1} \mathrm{NO}_{2}^{-}$was significantly lower than the biomass of juveniles exposed to other treatments after 20 days (Table 1). No significant relationship between $\mathrm{NO}_{2}^{-}$levels and the analyzed parameters was found.
Table 1. Effect of waterborne nitrite on weight, length, biomass and specific growth rate of silver catfish juveniles. $\mathrm{N}=3$ tanks.Values are expressed as mean \pm SEM. Different letters in the rows indicate significant difference among treatments by one-way ANOVA and Tukey test $(\mathrm{p}<0.05) .{ }^{*}=$ only one replicate; $* *=$ all fish dead.

\begin{tabular}{|c|c|c|c|c|}
\hline \multirow{2}{*}{ Time (days) } & \multicolumn{4}{|c|}{ Nitrite $\left(\mathrm{mg} . \mathrm{L}^{-1}\right)$} \\
\hline & 0.06 & 0.46 & 1.19 & 1.52 \\
\hline \multicolumn{5}{|c|}{ Weight (g) } \\
\hline 20 & $3.61 \pm 0.20^{\mathrm{a}}$ & $3.72 \pm 0.33^{\mathrm{a}}$ & $3.89 \pm 0.33^{\mathrm{a}}$ & $3.62 \pm 0.23^{\mathrm{a}}$ \\
\hline 40 & $4.42 \pm 0.27^{\mathrm{a}}$ & $\begin{array}{l}4.34 \pm 0.43^{\mathrm{a}} \\
\text { Length }(\mathrm{mm})\end{array}$ & $4.42 \pm 0.46^{\mathrm{a}}$ & $* *$ \\
\hline 20 & $63.0 \pm 1.0^{\mathrm{a}}$ & $63.4 \pm 1.8^{\mathrm{a}}$ & $63.8 \pm 1.5^{\mathrm{a}}$ & $* 62.8 \pm 1.4$ \\
\hline 40 & \multicolumn{3}{|c|}{ Biomass $(\mathrm{g})$} & $* *$ \\
\hline 20 & $36.12 \pm 1.37^{\mathrm{a}}$ & $36.83 \pm 1.89^{\mathrm{a}}$ & $38.92 \pm 2.24^{\mathrm{a}}$ & $10.73 \pm 18.58^{b}$ \\
\hline 40 & $44.20 \pm 2.36^{\mathrm{a}}$ & $43.37 \pm 2.64^{\mathrm{a}}$ & $44.17 \pm 3.33^{\mathrm{a}}$ & $* * 0.0^{\mathrm{b}}$ \\
\hline \multicolumn{5}{|c|}{ Specific growth rate $\left(\%\right.$. day $\left.^{-1}\right)$} \\
\hline 20 & $0.97 \pm 0.11^{\mathrm{a}}$ & $1.06 \pm 0.18^{\mathrm{a}}$ & $1.27 \pm 0.23^{\mathrm{a}}$ & $* 0.70$ \\
\hline 40 & $1.98 \pm 0.24^{\mathrm{a}}$ & $1.82 \pm 0.25^{\mathrm{a}}$ & $1.89 \pm 0.33^{\mathrm{a}}$ & $* *$ \\
\hline
\end{tabular}

Silver catfish maintained at $1.19 \mathrm{mg} \cdot \mathrm{L}^{-1} \mathrm{NO}_{2}^{-}$presented significantly higher lactate levels in the liver than control fish and those exposed to $0.46 \mathrm{mg} \cdot \mathrm{L}^{-1} \mathrm{NO}_{2}^{-}$. In addition, protein levels in the liver were significantly higher in fish exposed to $1.19 \mathrm{mg} . \mathrm{L}^{-1} \mathrm{NO}_{2}{ }^{-}$compared to control fish and those exposed to $0.46 \mathrm{mg}$. $\mathrm{L}^{-1} \mathrm{NO}_{2}^{-}$. Glucose levels in the liver of fish exposed to $1.52 \mathrm{mg} . \mathrm{L}^{-1} \mathrm{NO}_{2}^{-}$were significantly lower than in fish exposed to $1.19 \mathrm{mg} . \mathrm{L}^{-1} \mathrm{NO}_{2}^{-}$. Glycogen levels in the liver of fish exposed to $1.19 \mathrm{mg} . \mathrm{L}^{-1} \mathrm{NO}_{2}^{-}$were significantly lower than in fish exposed to $0.46 \mathrm{mg} . \mathrm{L}^{-1} \mathrm{NO}_{2}^{-}$. Lactate levels were significantly lower in the muscle of fish exposed to all $\mathrm{NO}_{2}^{-}$levels compared to control fish. Glucose content in the muscle of fish exposed to $1.52 \mathrm{mg} . \mathrm{L}^{-1} \mathrm{NO}_{2}{ }^{-}$was significantly lower than in fish exposed to 0.49 and $1.19 \mathrm{mg} \cdot \mathrm{L}^{-1} \mathrm{NO}_{2}^{-}$. Glycogen and protein levels in the muscle were not affected by $\mathrm{NO}_{2}^{-}$exposure (Table 2).

\section{Discussion}

Nitrite $\mathrm{LC}_{50-96 \mathrm{~h}}$ values are affected by waterborne $\mathrm{Cl}^{-}$(Russo \& Thurston, 1977; Wise \& Tomasso, 1989; Atwood et al., 2001), fish weight (Russo et al., 1974; Palachek \& Tomasso 1984a; Atwood et al., 2001), pH (Russo et al., 1981), and species (Palachek \& Tomasso, 1984a). Consequently, $\mathrm{NO}_{2}^{-}$ $\mathrm{LC}_{50-96 \mathrm{~h}}$ values are extremely variable, ranging from 0.19-0.56 mg. $\mathrm{L}^{-1}$ in rainbow trout (Russo et al., 1974; Russo \& Thurston, 1977) and cutthroat trout, Salmo clarkii (= Oncorynchus clarkii) (Thurston et al., 1978), up to $150-230 \mathrm{mg} . \mathrm{L}^{-1}$ in fathead minnows, Pimephales promelas (Palachek \& Tomasso, 1984b). Nitrite $\mathrm{LC}_{50-}$ ${ }_{96 \mathrm{~h}}$ value for silver catfish juveniles is $20.46 \mathrm{mg} \cdot \mathrm{L}^{-1} \mathrm{NO}_{2}^{-}$.

The $\mathrm{NO}_{2}^{-} \mathrm{LC}_{50-96 \mathrm{~h}}$ values determined for the neotropical fishes matrinxã, Brycon amazonicus ( $45 \mathrm{~g}, 0.86 \mathrm{mg} . \mathrm{L}^{-1}$ ) (Avilez et al., 2004) and tambaqui, Colossoma macropomum (65 g, $\left.1.82 \mathrm{mg} . \mathrm{L}^{-1}\right)($ Costa et al., 2004) are much lower than for silver catfish. However, it must be considered that in both experiments waterborne $\mathrm{Cl}^{-}$levels were also much lower $(0.35$ $0.5 \mathrm{mg} . \mathrm{L}^{-1}$ ) (Avilez et al., 2004; Costa et al., 2004) than in the 
Table 2. Metabolic parameters of liver and muscle of silver catfish juveniles exposed to different waterborne nitrite levels for 40 days. Lactate, glycogen and glucose in $\mu \mathrm{mol.g} \mathrm{g}^{-1}$. Protein in $\mathrm{mg} . \mathrm{g}^{-1} . \mathrm{N}=10$. Values are expressed as mean $\pm \mathrm{SEM}$. Different letters in the rows indicate significant difference among treatments by one-way ANOVA and Tukey test $(\mathrm{p}<0.05)$.

\begin{tabular}{lcccc}
\hline \multicolumn{5}{c}{ Nitrite $\left(\mathrm{mg} . \mathrm{L}^{-1}\right)$} \\
\hline Liver & 0.06 & 0.46 & 1.19 & 1.52 \\
Lactate & & & $7.9 \pm 0.48^{\mathrm{b}}$ & $6.8 \pm 0.61^{\mathrm{bc}}$ \\
Glycogen & $5.12 \pm 0.29^{\mathrm{ac}}$ & $4.05 \pm 0.28^{\mathrm{a}}$ & $37.98 \pm 2.50^{\mathrm{b}}$ & $42.76 \pm 5.52^{\mathrm{ab}}$ \\
Protein & $48.85 \pm 3.52^{\mathrm{ab}}$ & $51.83 \pm 3.83^{\mathrm{a}}$ & $421.90 \pm 21.30^{\mathrm{a}}$ & $389.47 \pm 15.17^{\mathrm{ab}}$ \\
Glucose & $412.41 \pm 15.16^{\mathrm{a}}$ & $303.60 \pm 23.48^{\mathrm{b}}$ & & $2242.62 \pm 87.08^{\mathrm{b}}$ \\
Muscle & $2383.92 \pm 47.80^{\mathrm{ab}}$ & $2346.96 \pm 28.57^{\mathrm{ab}}$ & $2516.36 \pm 34.30^{\mathrm{a}}$ & \\
Lactate & & & & \\
Glycogen & $13.90 \pm 1.06^{\mathrm{a}}$ & $8.77 \pm 0.80^{\mathrm{b}}$ & $5.87 \pm 0.44^{\mathrm{b}}$ & $7.87 \pm 0.70^{\mathrm{b}}$ \\
Protein & $6.55 \pm 0.46^{\mathrm{a}}$ & $7.40 \pm 0.61^{\mathrm{a}}$ & $5.50 \pm 0.23^{\mathrm{a}}$ & $7.08 \pm 0.80^{\mathrm{a}}$ \\
Glucose & $208.00 \pm 4.76^{\mathrm{a}}$ & $220.32 \pm 14.76^{\mathrm{a}}$ & $205.47 \pm 10.24^{\mathrm{a}}$ & $207.53 \pm 5.55^{\mathrm{a}}$ \\
\hline & $1.16 \pm 0.06^{\mathrm{ab}}$ & $1.30 \pm 0.10^{\mathrm{a}}$ & $1.27 \pm 0.07^{\mathrm{a}}$ & $1.03 \pm 0.03^{\mathrm{b}}$ \\
\hline
\end{tabular}

experiment with silver catfish $\left(3.9 \mathrm{mg} \cdot \mathrm{L}^{-1}\right)$. Rainbow trout $(69 \mathrm{~g})$ maintained at $5.1 \mathrm{mg} . \mathrm{L}^{-1}$ waterborne $\mathrm{Cl}^{-}$levels, i.e., similar to the levels used in the present study with silver catfish, presents $\mathrm{NO}_{2}^{-} \mathrm{LC}_{50-96 \mathrm{~h}}$ of $2.36 \mathrm{mg} . \mathrm{L}^{-1}$ (Russo \& Thurston, 1977). In another experiment, a higher $\mathrm{NO}_{2}^{-} \mathrm{LC}_{50-96 \mathrm{~h}}$ value $\left(11.2 \mathrm{mg} . \mathrm{L}^{-1}\right)$ was found for rainbow trout of $16.3 \mathrm{~g}$ (Kroupova et al., 2008), but probably because waterborne $\mathrm{Cl}^{-}$levels were also higher in this study (10 mg. $\left.\mathrm{L}^{-1}\right)$ than that of Russo \& Thurston (1977). Nitrite $\mathrm{LC}_{50-96 \mathrm{~h}}$ value found for silver catfish is also higher than those determined for $3.0 \mathrm{~g}$ channel catfish and $3.4 \mathrm{~g}$ tilapia, Tilapia aurea (= Oreochromis aureus) (7.1 and 16.2 $\mathrm{mg} . \mathrm{L}^{-1}$, respectively), but lower than those found for largemouth bass, Micropterus salmoides (140.2 mg. $\left.\mathrm{L}^{-1}\right)$, of $2.8 \mathrm{~g}$, all species kept at $22 \mathrm{mg} . \mathrm{L}^{-1} \mathrm{Cl}^{-}$(Palachek \& Tomasso, 1984a). Therefore, silver catfish is comparatively resistant to $\mathrm{NO}_{2}^{-}$.

Waterborne $\mathrm{NO}_{2}^{-}$levels up to $1.19 \mathrm{mg} \cdot \mathrm{L}^{-1}$ does not affect weight, biomass, specific growth rate, or survival of silver catfish. Similarly, $18.9 \mathrm{~g}$ rainbow trout exposed to $3.0 \mathrm{mg} . \mathrm{L}^{-1}$ $\mathrm{NO}_{2}^{-}\left(10 \mathrm{mg} \cdot \mathrm{L}^{-1} \mathrm{Cl}^{-}\right)$presented lower weight and $65 \%$ mortality after 28 days, but those maintained at $1.0 \mathrm{mg} . \mathrm{L}^{-1} \mathrm{NO}_{2}^{-}$did not show any difference from control group (Kroupova et al., 2008). Exposure of 6-7 g silver perch to $\mathrm{NO}_{2}^{-}$levels higher than $1.43 \mathrm{mg} . \mathrm{L}^{-1}$ for 25 days reduced growth, but levels up to $16.2 \mathrm{mg} . \mathrm{L}^{-1}$ did not cause mortality (Frances et al., 1998). As explained previously, silver catfish $\mathrm{NO}_{2}^{-} \mathrm{LC}_{50-96 \mathrm{~h}}$ is higher than that of channel catfish, but channel catfish can be acclimated for 15 days in up to $6.3 \mathrm{mg} . \mathrm{L}^{-1}$ without mortality; however, these fish exhibited reduced growth and anemia (Urrutia \& Tomasso, 1987).

Fish exposed to $\mathrm{NO}_{2}^{-}$- demonstrate decreased functional hemoglobin blood levels because hemoglobin is converted into methemoglobin (Aggergaard \& Jensen, 2001). The increase of methemoglobin levels can be observed by the appearance of asphyxia symptoms (Spotte, 1979). In the present experiment, apparently silver catfish juveniles tried to minimize the effect of asphyxia by swimming near the water's surface. Similar behavior was previously reported by Braun et al. (2006) in silver catfish exposed to hypoxia and in several species exposed to $\mathrm{NO}_{2}^{-}$(Parma-de-Croux, 1994; Burleson et al., 2002; Chapman et al., 2002; Delaney \& Klesius, 2004).
Lactate is the end product of glycolysis in hypoxic conditions. Exposure of silver catfish to $\mathrm{NO}_{2}^{-}$reduce lactate levels in muscle, but lactate levels increase in the liver of fish maintained at $1.19 \mathrm{mg} . \mathrm{L}^{-1} \mathrm{NO}_{2}^{-}$. In addition, glucose levels in the muscle and liver is significantly lower in silver catfish exposed to the highest $\mathrm{NO}_{2}{ }^{-}$level. Acute exposure $(8 \mathrm{~h})$ to $20-$ $30 \mathrm{mg} . \mathrm{L}^{-1} \mathrm{NO}_{2}^{-}$also decreased glucose in the liver and white muscle and lactate in the muscle of pacu (Piaractus mesopotamicus) (Moraes et al., 2006), and glucose in the red muscle and heart of traira (Moraes et al., 1998). However, in tambacu the same treatment increased glucose and lactate in the liver and plasma (Moraes et al., 2006), and in traira increased lactate in the red muscle and plasma (Moraes et al., 1998).

The results indicate that chronic $\mathrm{NO}_{2}^{-}$exposure in silver catfish causes anaerobic substrate oxidation to meet energy demand. This may be due to the transformation of functional hemoglobin to methemoglobin that may occur in fish exposed to $\mathrm{NO}_{2}^{-}$. An increase of lactate content indicates metabolic disorders and may suggest severe respiratory stress (Begum \& Vijayaraghavan, 1999). This is the first study to demonstrate metabolic alterations in fish provoked by chronic $\mathrm{NO}_{2}{ }^{-}$ exposure. The need of silver catfish exposed to chronic $\mathrm{NO}_{2}$ to obtain at least part of its energy through the use of an anaerobic pathway might help explaining a lower growth, but in the present study a relationship with mortality could not be seen because the changes were not proportional to $\mathrm{NO}_{2}-$ levels.

Some metabolic responses are similar to those observed after acute $\mathrm{NO}_{2}{ }^{-}$exposure in other neotropical species (Moraes et al., 1998, 2006), but additional studies must be performed to state if the differences found are species-specific or due to length of exposure. In addition, in the present study is showed that silver catfish is comparatively resistant to $\mathrm{NO}_{2}^{-}$, since its $\mathrm{LC}_{50-96 \mathrm{~h}}$ is $20.46 \mathrm{mg} \cdot \mathrm{L}^{-1}$. The safe $\mathrm{NO}_{2}^{-}$level for silver catfish juvenile growth is below $1.19 \mathrm{mg} . \mathrm{L}^{-1}$, i.e., $4.8-5.8 \% \mathrm{LC}_{50-96 \mathrm{~h}}$, and higher $\mathrm{NO}_{2}^{-}$levels caused mortality.

\section{Acknowledgements}

J. Radünz Neto and B. Baldisserotto received research fellowships from Conselho Nacional de Desenvolvimento 
Tecnológico (CNPq), and R.L. Lima, R. Lazzari and N. Braun received fellowships from Coordenação de Aperfeiçoamento de Pessoal de Nível Superior (CAPES).

\section{Literature Cited}

Aggergaard, S. \& F. B. Jensen. 2001. Cardiovascular changes and physiological response during nitrite exposure in rainbow trout. Journal of Fish Biology, 59: 13-27.

Andrade, L. S., R. L. B. Andrade, A. G. Becker, L. V. Rossato, J. F. Rocha \& B. Baldisserotto. 2007. Interaction of water alkalinity and stocking density on survival and growth of silver catfish, Rhamdia quelen, juveniles. Journal of the World Aquaculture Society, 38: 454-458.

Atwood, H. L., Q. C. Fontenot, J. R. Tomasso \& J. J. Isely. 2001. Toxicity of nitrite to Nile tilapia: Effect of fish size and environmental chloride. North American Journal of Aquaculture, 63: 49-51.

Avilez, I. M., L. H. Aguiar, A. E. Altran, G. Moraes. 2004. Acute toxicity of nitrite to matrinxã, Brycon cephalus (Günther, 1869), (Teleostei-Characidae). Ciência Rural, 34: 1753-1756.

Avnimelech, Y., B. Weber, B. Hepher, A. Milstein \& M. Zorn. 1986. Studies in circulated fish ponds: organic matter recycling and nitrogen transformation. Aquaculture and Fisheries Management, 17: 231-242.

Baldisserotto, B. 2009. Piscicultura continental no Rio Grande do Sul: situação atual, problemas e perspectivas para o futuro. Ciência Rural, 39: 291-299.

Begum, G. \& S. Vijayaraghavan. 1999. Effect of acute exposure of the organophosphate insecticide Rogor on some biochemical aspects of Clarias batrachus (Linnaeus). Environmental Research, 80: 80-83.

Bianchini, A., W. Wasielesky \& K. C. Miranda. 1996. Toxicity of nitrogenous compounds to juveniles of flatfish Paralichthys orbignyanus. Bulletin of Environmental and Contamination Toxicology, 56: 453-459.

Bidinoto, P. M., R. H. S. Souza \& G. Moraes. 1997. Hepatic glycogen and glucose in eight tropical freshwater teleost fish: a procedure for field determinations of micro samples. Boletim Técnico do CEPTA, 10: 53-60.

Boyd, C. E. 1998. Water quality for pond aquaculture. Research and Development Series. International Center for Aquaculture and Aquatic Environments. Alabama, Auburn University, 3: 1-37.

Braun, N., R. L. Lima, B. Moraes, V. L. Loro \& B. Baldisserotto. 2006. Survival, growth and biochemical parameters of silver catfish, Rhamdia quelen (Quoy \& Gaimard, 1824), juveniles exposed to different dissolved oxygen levels. Aquaculture Research, 37: 1524-1531.

Burleson, M. L., A. L. Carlton \& P. E. Silva. 2002. Cardioventilatory effects of acclimatization to aquatic hypoxia in channel catfish. Respiratory Physiology and Neurobiology, 131: 223-232.

Chapman, L. J., C. A. Chapman, F. G. Nordlie \& A. E. Rosenberger. 2002. Physiological refuge: swamps, hypoxia tolerance and maintenance of fish diversity in the Lake Victoria region. Comparative Biochemistry and Physiology Part A, 133(9): 421437.

Collins, M. T., J. B. Gratzek, E. B. Shotts Jr., D. L. Dawe, L. M. Campbell \& D. R. Senn. 1975. Nitrification in an aquatic recirculating system. Journal of the Fisheries Research Board of Canada, 32: 2025-2031.
Costa, O. T. F., D. J. S. Ferreira, F. L. P. Mendonça \& M. N. Fernandes. 2004. Susceptibility of the Amazonian fish, Colossoma macropomum (Serrasalminae), to short-term exposure to nitrite. Aquaculture, 232: 627-636.

Delaney, M. A. \& P. H. Klesius. 2004. Hypoxic conditions induce Hsp70 production in blood, brain and head kidney of juvenile Nile tilapia Oreochromis niloticus (L). Aquaculture, 236: 633644.

Finney, D. J. 1971. Probit Analysis. Cambridge University Press. Cambridge, England, 337p.

Frances, J., G. L. Allan \& B. F. Nowak. 1998. The effects of nitrite on the short-term growth of silver perch (Bidyanus bidyanus). Aquaculture, 163: 63-72.

Garcia, L. O., A. G. Becker, C. E. Copatti, J. Radünz Neto \& B. Baldisserotto. 2007. Salt in the food and water as a supportive therapy for Ichthyophthirius multifiliis infestation on silver catfish, Rhamdia quelen, fingerlings. Journal of the World Aquaculture Society, 38: 1-11.

Greenberg, A. E., M. J. Taras \& M. C. Rand. 1976. Standard methods for the examination of water and waste water. Bru-El Graphic Inc., Springfield, Illinois, USA, 1084p.

Hargreaves, J. A. 1998. Nitrogen biogeochemistry of aquaculture ponds. Aquaculture, 166: 181-212.

Harrower, J. R. \& C. H. Brown. 1972. A micromethod adapted to field collection of microliter samples. Journal Applied Physics, 32: 709-711.

Holt, J. \& C. Arnold. 1996. Effects of ammonia and nitrite on growth and survival of red drum eggs and larvae. Transactions of the American Fisheries Society, 112: 558-562.

Jensen, F. B. 2003. Nitrite disrupts multiple physiological functions in aquatic animals. Comparative Biochemistry and Physiology Part A, 135: 9-24.

Jensen, F. B., N. A. Andersen \& N. Heisler. 1987. Effects of nitrite exposure on blood respiratory properties, acid-base and electrolyte regulation in the carp (Cyprinus carpio). Journal of Comparative Physiology, 157: 533-541.

Kamstra, A., J. A. Span \& J. H. Van Weerd. 1996. The acute toxicity and sublethal effects of nitrite on growth and feed utilization of European eel, Anguilla anguilla (L.). Aquaculture Research, 27: 903-911.

Kroupova, H., J. Machova, V. Piackova, J. Blahova, R. Dobsikova, L. Novotny \& Z. Svobodova. 2008. Effects of subchronic nitrite exposure on rainbow trout (Oncorhynchus mykiss). Ecotoxicology and Environmental Safety, 71: 813-820.

Lewis, W. M. \& D. P. Morris. 1986. Toxicity of nitrite to fish: a review. Transactions of the American Fisheries Society, 22: 227-238.

Lowry, D. H., N. J. Rosenbrough, A. L. Farr \& R. J. Randal. 1951. Protein measurement with folin phenol reagent. Journal of Biological Chemistry, 193: 265-275.

Moraes, G., I. M. Avilez \& T. S. F. Hori. 2006. Comparison between biochemical responses of the teleost pacu and its hybrid tambacu (Piaractus mesopotamicus x Colossoma macropomum) to short term nitrite exposure. Brazilian Journal of Biology, 66: 29-41.

Moraes, G., E. B. Cattony, \& R. H. S. Souza. 1998. Metabolic responses of the teleost Hoplias malabaricus to high levels of environmental nitrite. Revista Brasileira de Biologia, 58: 105-113.

Palachek, R. M. \& J. R. Tomasso. 1984a. Toxicity of nitrite to channel catfish (Ictalurus punctatus), tilapia (Tilapia aurea), and largemouth bass (Micropterus salmoides): evidence for a nitrite exclusion mechanism. Canadian Journal of Fisheries Aquatic Sciences, 41: 1739-1744. 
Palachek, R. M. \& J. R. Tomasso. 1984b. Nitrite toxicity to fathead minnows - effect of fish weight. Bulletin of Environmental Contamination and Toxicology, 32: 238-242.

Park, J. T. \& M. J. Johnson. 1949. A submicro determination of glucose. Journal of Biological Chemistry, 181: 149-151.

Parma-de-Croux, M. J. 1994. Metabolic rate and oxygen consumption requirements of some fish species from the middle Parana river. Acta Biologica de Venezuela, 15(2): 1-10.

Piper, G. R., I. B. McElwain, L. E. Orme, J. P. McCraren, L. G. Fowler \& J. R. Leonard. 1982. Fish hatchery management. United States Department of the Interior Fish and Wildlife Service, Washington, DC, USA.

Russo, R. C., C. E. Smith \& R. V. Thurston. 1974. Acute toxicity of nitrite to rainbow trout (Salmo gairdneri). Journal of the Fisheries Research Board of Canada, 31(10): 1653-1655.

Russo, R. C. \& R. V. Thurston. 1977. The acute toxicity of nitrite to fish. Pp. 118-131. In: Tubbs, R. A. (Ed.). Recent advances in fish toxicology. U.S. Environment Protection Agency, EPA Ecological Research Service, EPA-600/3-77-085, Corvallis.

Russo, R. C., R. V. Thurston \& K. Emerson. 1981. Acute toxicity of nitrite to rainbow trout (Salmo gairdneri) - effects of $\mathrm{pH}$, nitrite species, and anion species. Canadian Journal of Fisheries Aquatic Sciences, 38: 387-393.

Sipaúba-Tavares, L. H., M. A. G. Moraes \& F. M. S. Braga. 1999. Dynamics of some limnological characteristics in pacu (Piaractus mesopotamicus) culture tanks as function of handling. Revista Brasileira de Biologia, 59(4): 543-551.

Spotte, S. 1979. Fish and invertebrate culture. New York, John Wiley and Sons, $179 \mathrm{p}$.

Thurston, R. V., R. C. Russo \& C. E. Smith. 1978. Acute toxicity of ammonia and nitrite to cutthroat trout fry. Transactions of the American Fisheries Society, 107: 361-368.

Tomasso, J. R., 1994 Toxicity of nitrogenous wastes to aquaculture animals. Reviews of Fisheries Science, 2(4): 291-314.

Urrutia, M. L. \& J. R. Tomasso. 1987. Acclimation of channel catfish to environmental nitrite. Journal of the World Aquaculture Society, 18: 175-179.

Wise, D. J. \& J. R. Tomasso. 1989. Acute toxicity of nitrite to red drum Sciaenops ocellatus: effect of salinity. Journal of the World Aquaculture Society, 20: 193-198.

Zall, D. M., M. D. Fisher \& Q. M. Garner. 1956. Photometric determination of chlorides in water. Analytical Chemistry, 28: 1665-1678. 